\title{
Role of the hyporheic heterotrophic biofilm on transformation and toxicity of pesticides
}

\author{
J.M. Sánchez-Pérez ${ }^{1,2 *}$, B. Montuelle ${ }^{3,4}$, F. Mouchet ${ }^{1,2}$, L. Gauthier ${ }^{1,2}$, F. Julien ${ }^{1,2}$, S. Sauvage ${ }^{1,2}$,

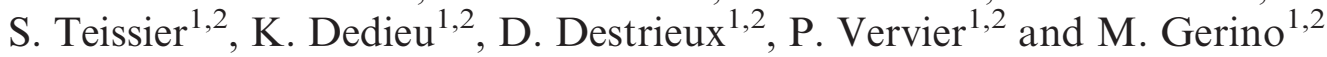 \\ ${ }^{1}$ University of Toulouse, INPT, UPS, Laboratoire Ecologie Fonctionnelle et Environnement (EcoLab), Avenue de l'Agrobiopole, \\ 31326 Castanet Tolosan Cedex, France \\ 2 CNRS, EcoLab, 31326 Castanet Tolosan Cedex, France \\ 3 IRSTEA Lyon, UR Qualité des Eaux, 3 bis quai Chauveau, CP 220, 69336 LYON Cedex 09, France \\ 4 Present address: INR-UMR Carrtel, 75 av. de Corzent - BP 511, 74203 Thonon, France
}

Received 9 October 2012; Accepted 22 March 2013

\begin{abstract}
The role of heterotrophic biofilm of water-sediment interface in detoxification processes was tested in abiotic and biotic conditions under laboratory conditions. Three toxicants, a herbicide (Diuron), a fungicide (Dimethomorph) and an insecticide (Chlorpyrifos-ethyl) have been tested in water percolating into columns reproducing hyporheic sediment. The detoxification processes were tested by comparing the water quality after 18 days of percolation with and without heterotrophic biofilm. Tested concentrations were $30 \mu \mathrm{g} . \mathrm{L}^{-1}$ of Diuron diluted in $0.1 \%$ dimethyl sulfoxide (DMSO), $2 \mu \mathrm{g} . \mathrm{L}^{-1}$ of Dimethomorph and $0.1 \mu \mathrm{g} . \mathrm{L}^{-1}$ of Chlorpyrifos-ethyl. To characterise the detoxification efficiency of the system, we performed genotoxicity bioassays in amphibian larvae and rotifers and measured the respiration and denitrification of sediments. Although the presence of biofilm increased the production of $N$-(3,4 dichlorophenyl)- $N$-(methyl)urea, a metabolite of diuron, the toxicity did not decrease irrespective of the bioassay. In the presence of biofilm, Dimethomorph concentrations decreased compared with abiotic conditions, from $2 \mu \mathrm{g} . \mathrm{L}^{-1}$ to $0.4 \mu \mathrm{g} . \mathrm{L}^{-1}$ after 18 days of percolation. For both Dimethomorph and Chlorpyrifos-ethyl additions, assessment of detoxification level by the biofilm depended on the test used: detoxification effect was found with amphibian larvae bioassay and no detoxification was observed with the rotifer test. Heterotrophic biofilm exerts a major influence in the biochemical transformation of contaminants such as pesticides, suggesting that the interface between running water and sediment plays a role in self-purification of stream reaches.
\end{abstract}

Key words: detoxification / hyporheic zone / diuron / dimethomorph / chlorpyriphos-ethyl

\section{Introduction}

Water quality assessment is strongly related to the global dimension of aquatic ecosystems including the interactions between ecology, hydrology and geomorphology (Everard and Powell, 2002). Among the ecosystem functions relative to water quality, the self-purifying capacity of a river is defined as its ability to improving water quality and to induce a chemical change in the dynamic equilibrium of the system (Marmonier et al., 2012). In the context of nutrient increase in surface waters, the study of this self-purifying capacity associated with nutrient retention in sediment is a relevant research domain. A focus on nitrogen and carbon uptake capacities of rivers leads to identification of river compartments that

\footnotetext{
*Corresponding author: jose.sanchez@univ-tlse3.fr
}

actively participate in nutrient transformation (Brugger et al., 2001; Battin et al., 2003; Peyrard et al., 2011; Navel et al., 2012). The hyporheic zone, a transition zone between groundwater and streams (Orghidan, 1959), is now recognised as a site of high biogeochemical activity (Pusch et al., 1998) that participates in stream ecosystem functioning by changing water quality (Stanford and Ward, 1993; White, 1993; Storey et al., 1999; Marmonier et al., 2012). Stream nutrient retention depends on several physical conditions such as water residence time (i.e., hydrological retention) (Lefebvre et al., 2006), as well as on biological and chemical processes affecting nutrient transport and transformation (House et al., 2001) and the interactions between these processes (Mermillod-Blondin et al., 2003).

In stream self-purification is largely controlled by the microbial communities that represent a large part of the 
biomass that develop in the hyporheic zone and are, for the most part, responsible for respiration, nutrient cycling and organic matter transformations (Grimm and Fisher, 1984; Pusch and Schwoerbel, 1994; Findlay, 1995) such as degradation of dissolved and particulate organic (Brunke and Gonser, 1997; Schindler and Krabbenhoft, 1998; Sánchez Pérez et al., 2003; Peyrard et al., 2011). In this sediment, organic matter is oxidised in aerobic or reduced in anaerobic conditions through different metabolic pathways, such as aerobic mineralisation, denitrification, iron and manganese reduction, sulfato-reduction and methanogenesis (e.g. Hunter et al., 1998; Baker et al., 2000). If the hyporheic compartment of rivers is often regarded as a significant bio-reactor with the potential to transform and reduce organic pollution (Gavrilescu, 2005; Jekel and Gruenheid, 2005; Wyss et al., 2006; Ifabiyi, 2008), but quantitative demonstration is still required for pesticides.

This observation leads to the framework hypotheses of the present study: if the hyporheic compartment is active as a bio-reactor at reducing natural dissolved and particulate matter loads, it may be possible that the same compartment performs transformation of some pesticides. Understanding these bioremediation processes requires one to closely integrate physical and biotic functioning of river systems at a variety of scales (Janauer, 2000; Sumpono et al., 2003), and the present paper is an attempt to simulate the hyporeic condition in laboratory microcosms.

There is little information on the retention of pesticides in field or laboratory conditions. In field assessments, pesticide load is demonstrated to decrease for all major families of pesticides (s-triazines, substituted ureas and anilides) in water along river reaches or in reservoir (Devault et al., 2009). In the field, concentration of pharmaceutical micropollutants decreased with depth in the hyporheic zone, but the reason for this reduction was not clear (Lewandowski et al., 2011). In bank filtration studies, Gruenheid et al. (2005) demonstrated that redox conditions and travel time significantly influence DOC degradation kinetics and the efficiency of absorbable organic halogens and trace compound removal.

If this self-purification capacity of natural systems also affects more resistant pollutants such as pesticides, it becomes pertinent to test in the laboratory the biological factors that influence their degradation. In laboratory microcosms investigations, Jekel and Gruenheid (2005), Gruenheid et al. (2005) and Baumgarten et al. (2011) demonstrated that in bank filtration, as in long retention soil column the major factors that influence the degradation of bulk and trace organics are redox conditions and retention times. In laboratory columns degradation of the antibiotic sulfamethoxazole takes months (Baumgarten et al., 2011) and led to the conclusion that it is essential to provide several weeks or even months of travel time in bank filtration to allow the degradation of this toxicant. The most efficient conditions to give evidence of this retention capacity must consider the physical, chemical and biological conditions of the natural that is to say microbial community of interstitial biofilm and reproduce it in artificial hyporheic sediment. Permanent water flow through the hyporheic zones explains why the biogeochemical processes in this transition zone are essential in mediating the water quality (Boulton et al., 1998). The experimental design adopted for the microcosms series is fixed to maintain vertical water circulation through the column of macroporous sediment with interstitial water flow in the range of in situ condition.

The effects of the heterotrophic biofilm on retention capacity of the hyporheic sediment are tested. From the literature, we just begin to understand the influence of microbiological organisms in transformation of organic micropollutants (Bogaerts et al., 2000; Bonnemoy et al., 2001). The ability of microbial diversity to participate in the bioremediative capacity of river beds applied to organic micropollutants is neither widely known in rivers nor in the hyporheos (Gifford et al., 2007). Therefore, there is a strong need for methodologies to estimate the hyporheic biodegradation of these pollutants that flow in the interstitial water (Williams et al., 2007; Landmeyer et al., 2010) with and without microbiological activity to give evidence of biofilm retention rate.

The objective of the work is to characterise the potential impact of microbial activity on water quality at the river subsurface-surface interface. Specifically, this paper focuses on (1) measuring the role of heterotrophic biofilm on retention and transformation of pesticides in water and (2) characterising the influence of this biofilm on potential toxicity of sediment water.

\section{Materials and methods}

We performed experiments in sediment columns mimicking river hyporheos, with water recirculating through the columns. To test the role of biofilm on the transformation of pesticides, some of the columns were previously treated to allow for biofilm development, some were not.

\section{Experimental design}

We set 24 Plexiglas columns $(20 \mathrm{~cm}$ in height, $6.8 \mathrm{~cm}$ internal diameter), and filled them with sand and gravel in successive layers, $2 \mathrm{~cm}$ thick, of 4 size ranges $\left(L_{1}=0.5-1 \mathrm{~mm}\right.$, $L_{2}=1-2 \mathrm{~mm}, L_{3}=2-10 \mathrm{~mm}$ and $\left.L_{4}=10-20 \mathrm{~mm}\right)$. Each gravel and sand layer was sieved manually with corresponding mesh before being autoclaved $\left(20 \mathrm{~min}\right.$ at $\left.121^{\circ} \mathrm{C}\right)$. The total mass of sediment in each column was equal to $1000 \pm 50 \mathrm{~g}$. Mean porosity, measured as the difference in weight of five columns dried and filled with water, corresponded to $34+3 \%$. A $300 \mu \mathrm{m}$ filter was positioned at the exit and entrance of the microcosm to both retain sedimentary particles within the column and to avoid modifying the porosity. Each microcosm was connected by silicone tubing (internal diameter $=3.2 \mathrm{~mm}$ ) to a highdensity polyethylene tank containing $15 \mathrm{~L}$ of filtered water (90 microns mesh size) from the Garonne River (France), 
collected some days before the beginning of the experiment. The water of different Plexiglas columns $(n=24)$ was put in circulation by peristaltic pumps (323Du Watson Marlow). The peristaltic pumps ensured a constant infiltration flow rate of 7-8 mL. $\mathrm{min}^{-1}$ (Darcian velocity $=1.39-1.59 \mathrm{~m}$. day $^{-1}$ ) similar to the in situ range of water flow in hyporheic sediments (Weng et al., 2003; Peyrard et al., 2008). Supplied water was aerated in tanks to maintain oxygen saturation. The global experimental device consisted of 24 microcosms with tanks and was installed in a dark room to avoid phototrophic biofilm development. Twelve sterile microcosms were set up without biofilm (biofilm is not developed during the experimentation in this condition) and 12 microcosms were set up with biofilm, with the three different toxicants being tested separately under two conditions. Room temperature was fixed at $15 \pm 0.5^{\circ} \mathrm{C}$.

\section{Experimental sampling and analysis}

The effects of biofilm were tested by comparison of two experimental conditions without biofilm (called abiotic condition) and with biofilm (called biotic condition) developed previously in the macroporous sediment.

Four replicates per condition were used to evaluate intra-condition variability compared with inter-condition variability. Sediment and water for the abiotic condition was autoclaved just before the beginning of water circulation to limit biofilm development in these microcosms. In the biotic columns, water circulation began two months before water circulation in abiotic columns.

\section{Experimental planning}

For biotic microcosms, the experiment lasted 90 days. After ten days of water circulation for stabilising hydraulic functioning in microcosms, in each reservoir, the water was enriched with $\mathrm{KNO}_{3}$ in order to reach a final concentration of $\mathrm{N}_{-} \mathrm{NO}_{3}^{-}$equal to $10 \mathrm{mg} . \mathrm{L}^{-1}$ and with $\mathrm{CH}_{3} \mathrm{COONa}, 3 \mathrm{H}_{2} \mathrm{O}$ in order to reach a final concentration of DOC equal to $30 \mathrm{mg} . \mathrm{L}^{-1}$. Nutrients inputs were chosen to be high enough to prevent total consumption between two nutrient additions and allow constant biofilm development. Nutrient injections were added once a week throughout the experiment to adjust the same final concentrations. To limit biofilm development under the abiotic condition, these microcosms were started only one week before addition of pesticides.

Tested concentrations for pesticides were $30 \mu \mathrm{g} . \mathrm{L}^{-1}$ of Diuron (CAS number: 330-54-1; $\log \mathrm{Kow}=2.78$ ) diluted in $0.1 \%$ DMSO, $2 \mu \mathrm{g} . \mathrm{L}^{-1}$ of Dimethomorph (CAS number $=110488-70-5$, log Kow Isomère $E=2.63$ ) and $0.1 \mu \mathrm{g} . \mathrm{L}^{-1}$ of Chlorpyrifos-ethyl (CAS number 2921-88-2 and $\log \mathrm{Kow}=4.96)$. Diuron is solid at ambient temperature (melting point $=160{ }^{\circ} \mathrm{C}$ ), hence we dissolved it in DMSO $0.1 \%$ before injection.

\section{Biomass measurement}

The weight of the interstitial biofilm was determined at the end of the experiment by ash free dry measurements. Two samples of sediment $(50 \mathrm{~g})$ collected at the top and bottom of each column were dried in an incubator at $105^{\circ} \mathrm{C}$ for $48 \mathrm{~h}$ and then burned-off at $500^{\circ} \mathrm{C}$ for $5 \mathrm{~h}$. Averaged values between top and bottom samples of each microcosm were used.

\section{Physico-chemical analyses}

Microcosms were kept recirculating for one month for biofilm to reach equilibrium. Afterwards, water was analysed weekly during the 18 days of the experiment. Dissolved oxygen was measured at the outlet of the columns and additional water samples were taken from the reservoir containing the recirculated water to measure nitrate, nitrite, ammonium and dissolved organic carbon. Nitrate, nitrite and ammonium were measured using a high performance ion chromatographic analyser (DIONEX, DX500 and DX120). Water samples were filtered through cellulose acetate membranes $(25 \mathrm{~mm}$ diameter, $0.2 \mu \mathrm{m}$ pore size and VWR). For dissolved $\mathrm{O}_{2}$ measurements, a measuring chamber containing an electrode WTW CellOx 325 (pre-calibrated) was incorporated into water circulation at the outlet of the column. For DOC measurements, water samples were filtered through Whatman $\mathrm{GF} / \mathrm{F}$ glass-fiber filters $(0.7 \mu \mathrm{m}$ pore size, $25 \mathrm{~mm}$ diameter) pre-combusted at $500{ }^{\circ} \mathrm{C}$ for $4 \mathrm{~h}$. Filtrates were acidified with concentrated hydrochloric acid $(6 \mathrm{~N})$ until $\mathrm{pH}<2(10 \mu \mathrm{L} \mathrm{HCl}$ per $\mathrm{mL}$ of filtrate $)$ and kept in $8 \mathrm{~mL}$ glass tubes in the refrigerator pre-combusted at $500{ }^{\circ} \mathrm{C}$. DOC was measured using a Total Organic Carbon Analyzer (Shimadzu TOC-5000A).

Dimethomorph, Chlorpyriphos-ethyl, Diuron and two of its main metabolites (3-(3,4-dichlorophenyl)-1-methyl urea (DCPMU) and 3,4-dichloroaniline (DCA)) were measured in water by ESI-LC-MS/MS (API 4000, Applied Biosystems) at the end of the experiment, 18 days after injection. Detection limit is $0.5 \mu \mathrm{g} . \mathrm{L}^{-1}$ for Dimethomorph, $0.08 \mu \mathrm{g} . \mathrm{L}^{-1}$ for Chlorpyriphos-ethyl, and $0.01 \mu \mathrm{g} . \mathrm{L}^{-1}$ for Diuron and its main metabolites.

\section{Biological tests}

Ecotoxicological investigations were performed using the standardised (ISO, 2006) amphibian micronucleus test (MNT) on Xenopus laevis larvae to assess the potential detoxification of the three toxicants by the biofilm. The MNT allows the evaluation of potential genotoxicity of pure substances or mixed substances of the exposure media (Mouchet and Gauthier, 2013). The sensitivity and reliability of the MNT applied to amphibians as biomarker, to detect chromosomal and/or genomic mutations makes it a sensitive method to analyse the potential cytogenetic damage caused by various contaminants. 
This method has been standardised on Xenopus laevis, in French (AFNOR, 2000) and International (ISO, 2006) recommendations. It consists of measuring the number of erythrocytes with micronucleated cells in the circulating blood of Xenopus laevis larvae. Larvae were obtained after in vivo fertilisation and maintained for about three weeks in aquariums at $20^{\circ} \mathrm{C} \pm 2{ }^{\circ} \mathrm{C}$ until the appropriate developmental stage (i.e. st. 50) (Nieuwkoop and Faber, 1956). The MNT was conducted as described in the ISO guideline 21427-1 on water samples from various conditions to be tested. Larvae were exposed for 12 days at $22^{\circ} \mathrm{C} \pm 2{ }^{\circ} \mathrm{C}$ under normal photoperiod in groups of $15(100 \mathrm{~mL}$ per larva) in 5-L glass flasks containing $1.5 \mathrm{~L}$ of water, including the negative and positive controls. The negative control (NC) was the reconstituted water alone (294 mg.L ${ }^{-1} \mathrm{CaCl}_{2} \cdot 2 \mathrm{H}_{2} \mathrm{O}, 123.25 \mathrm{mg} . \mathrm{L}^{-1} \mathrm{MgSO}_{4} \cdot 7 \mathrm{H}_{2} \mathrm{O}$, $64.75 \mathrm{mg} . \mathrm{L}^{-1} \mathrm{NaHCO}_{3}, 5.75 \mathrm{mg} . \mathrm{L}^{-1} \mathrm{KCl}$ ). The positive control (PC) was cyclophosphamide monohydrate (a wellknown mutagenic agent) added to the reconstituted water at $20 \mathrm{mg} . \mathrm{L}^{-1}$. The experiments were conducted in semistatic conditions over the 12 days of exposure. Media were renewed daily. After exposure, the number of micronucleated cells per thousand present in a blood smear sampled by cardiac puncture of each animal were scored under a photonic microscope.

Rotifer test was made according to the French AFNOR norm (NF T 90-377 December 2000). Female Brachionus calyciflorus (Toxkit Cysts Microtests Inc.) reproduction is measured $48 \mathrm{~h}$ after exposure to the pollutant. Before exposure females were isolated in a box with a nutritional supply (Chlorella vulgaris). Reproduction rate was calculated on the basis of the number of eggs produced during exposure. Data were expressed in CE 50 (inhibition of $50 \%$ of the reproduction rate) and calculated with RegTox code (http://eric.vindimian.9online.fr).

\section{Micro-organisms activities}

Aerobic respiration and denitrification were measured at the end of the experiment following the slurry technique (Furutani et al., 1984). About $10 \mathrm{~g}$ of wet mixed sediment collected both from the top and the bottom layers was placed in $150 \mathrm{~mL}$ flasks supplemented with a feeding solution, in order to optimise microbial activity. For the measurement of $\mathrm{CO}_{2}$ production (respiration), incubation was realised under aerobiosis with $5 \mathrm{~mL}$ of a feeding solution of glucose $\left(7.5\right.$ g. $\left.\mathrm{L}^{-1}\right)$ and glutamic acid (7.3 g. $\left.\mathrm{L}^{-1}\right)$. For the measurements of $\mathrm{N}_{2} \mathrm{O}$ production (denitrification), the incubation was performed under anaerobic conditions with an $\mathrm{N}_{2}$ atmosphere. The feeding solution was a mixture of $5 \mathrm{~mL}$ of $\mathrm{KNO}_{3}\left(2.2\right.$ g.L $\left.{ }^{-1}\right)$, glucose $\left(7.5 \mathrm{~g} . \mathrm{L}^{-1}\right)$ and glutamic acid $\left(7.3 \mathrm{~g} . \mathrm{L}^{-1}\right)$. The incubation flasks were then filled with helium atmosphere. The sequence was repeated three times and internal pressure was adjusted to a pressure of 1 atmosphere. After removal of $15 \mathrm{~mL}$ of $\mathrm{He}$ from the incubation flasks, $15 \mathrm{~mL}$ of $\mathrm{C}_{2} \mathrm{H}_{2}(10 \% \mathrm{v} / \mathrm{v}$ final volume) was added to inhibit $\mathrm{N}_{2} \mathrm{O}$ reductase. All incubations were carried out at $20{ }^{\circ} \mathrm{C}$, in the dark and gently shaken. At $t=3 \mathrm{~h}$ and $t=6 \mathrm{~h}$, gases $\left(\mathrm{C}-\mathrm{CO}_{2}\right.$ and $\left.\mathrm{N}-\mathrm{NO}_{2}\right)$ were measured by gas chromatography model on an MTI 200 microcatharometer and dry weights of sediment were determined after drying at $60^{\circ} \mathrm{C}$ to express the results as $\mu \mathrm{g}$ of $\mathrm{C}$ or $\mathrm{N}$ per hour and per gram of dry weight sediment $\left(\mu \mathrm{g} \cdot \mathrm{h}^{-1} \cdot \mathrm{g}_{\mathrm{sed}}^{-1} \mathrm{DW}\right)$.

In order to understand the effects of DMSO addition in the diuron experiment in a better manner, complementary experiments were run to compare the effect on microbial activities (glucosidase and amino-peptidase, denitrification rates) and respiration of DMSO alone at $0.1 \%$, Diuron alone at $30 \mu \mathrm{g} . \mathrm{L}^{-1}$, a mixture of Diuron $30 \mu \mathrm{g} . \mathrm{L}^{-1}$ and DMSO $0.1 \%$, a control without toxicant.

\section{Statistics}

Differences in bioassay were considered significant at $P<0.05$. All statistical calculations, including ANOVA, were performed using a Minitab computer package (Minitab Inc., USA).

Since the micronuclei were not distributed normally, median values and confidence intervals were calculated instead of means, using the statistical method described by McGill et al., (1978). The results of each test were (i) considered to be negative for genotoxicity if the confidence intervals determined from the negative control and the test condition shared common values (ii) considered to be positive if the confidence intervals determined for the negative control and the test condition did not share common values, and the median value of the test condition was twice that of the negative control.

\section{Results}

Microbial biomass averaged $0.22 \pm 0.05$ g per microcosm in the abiotic condition and $0.24 \pm 0.03 \mathrm{~g}$ per microcosms in the biofilm condition. The occurrence of a significant AFDM in both the conditions is due to detritus residues fraction included in the sediment that were collected in natural river bed before sterilisation. The slight difference between conditions is interpreted by the occurrence of a growing biofilm in the sediment column that reach $0.025 \mathrm{mg}$ of dried biomass.g ${ }^{-1}$ of sediment in some of the columns at the end of the experiment.

Oxygen concentration (mean $\pm \mathrm{SD}$ ) at the outlet of the microscosms was respectively in conditions without and with biofilm $3.40 \pm 1.02$ and $1.97 \pm 0.43$ for microcosms with diuron and DMSO; $4.86 \pm 2.3$ and $3.23 \pm 1.62$ with Chlorpyrifos-ethyl, and $5.19 \pm 2.3$ and $4.18 \pm 1.14$ with Dimethomorph. Oxygen consumption with diuron was estimated at $72.97 \pm 17.47$ and $89.55 \pm 8.55$ mg.d ${ }^{-1}$ in each experimental unit (15 1) without and with biofilm respectively, with Chlorpyrifos-ethyl $55.37 \pm 27.48$ and $74.04 \pm 35.00$, and with Dimethomorph $53.20 \pm 25.89$ and $62.88 \pm 30.10$. These changes in consumption are 


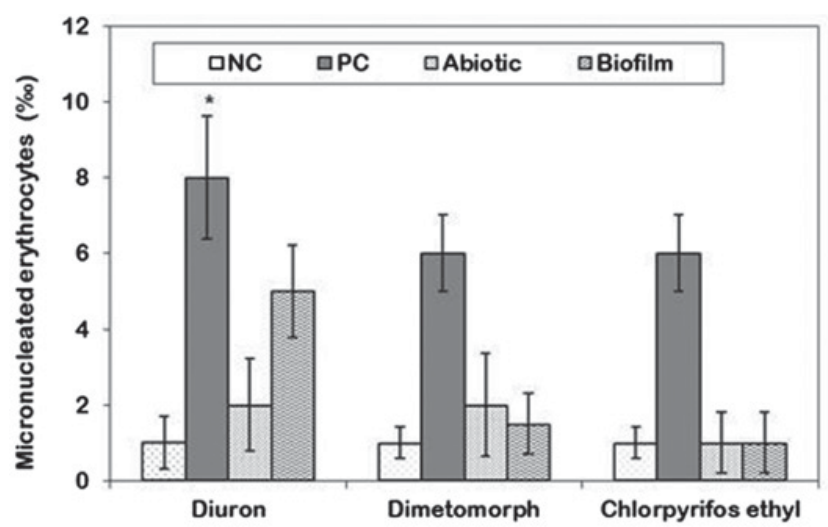

Fig. 1. Results of micronucleus test (genotoxicity) for Diuron, Dimethomorph and Chlorpyrifos-ethyl additions. NC, negative control; PC, positive control. Error bars are confidence interval $(95 \%)$. *Indicates genotoxicity compared with NC.

summarised by an average increase of $20 \%$ of aerobic respiration with interstitial biofilm in the sediment units.

The pesticides did not affect the consumption of carbon and nitrogen, which ranged from 1.91 to $2.17 \mathrm{mg} \mathrm{N}^{-1 \mathrm{day}^{-1}}$ and from 30.7 to $31.2 \mathrm{mg} \mathrm{C.day}{ }^{-1}$ in the biofilm experiment.

One day after addition, the Diuron concentrations were $25.0 \pm 2.7 \mu \mathrm{g} . \mathrm{L}^{-1}$ (mean $\pm \mathrm{SD}$ ). Eighteen days after addition in abiotic and biofilm conditions, Diuron concentrations were $21.8 \pm 1.7 \mu \mathrm{g} . \mathrm{L}^{-1}$ and $22.0 \pm 1.3 \mu \mathrm{g} . \mathrm{L}^{-1}$, respectively, and DCPMU concentrations were $0.06 \pm 0.01 \mu \mathrm{g} . \mathrm{L}^{-1}$ in the abiotic and $0.54 \pm 0.15$ $\mu \mathrm{g} . \mathrm{L}^{-1}$ in the biofilm conditions. The 3-4 DCA molecules were under detection limit in all cases. Four days after addition, the Dimethomorph concentration was $1.44 \pm 0.06 \mu \mathrm{g} . \mathrm{L}^{-1}$ in both conditions. After 18 days, Dimethomorph concentrations were $1.17 \pm 0.06 \mu \mathrm{g} . \mathrm{L}^{-1}$ in the abiotic conditions and below detection limit $\left(0.5 \mu \mathrm{g} . \mathrm{L}^{-1}\right)$ in the biofilm condition. Chlorpyrifos-ethyl concentrations were found under the detection limit of the apparatus $\left(0.08 \mu \mathrm{g} . \mathrm{L}^{-1}\right)$ during the whole period after addition. These concentrations lower than $0.08 \mu \mathrm{g} . \mathrm{L}^{-1}$ attest to a Chlorpyrifos-ethyl degradation at least equal to $20 \%$ of the initial loads in all conditions.

The genotoxic response obtained in larvae exposed to PC (positive control), compared with negative control (NC), validates the Xenopus laevis larvae strain used in this experiment. Larvae exposed to effluents flowing through abiotic conditions did not show any genotoxic response compared with negative control, whatever the nature of the toxicant used. Larvae of Xenopus laevis showed no genotoxic response when subject to either Dimethomorph or Chlorpyriphos-ethyl, but showed significant response when subject to Diuron/DMSO contamination. This response was stronger in the "biofilm" treatment (Fig. 1).

Rotifer tests performed with the Diuron/DMSO showed that the presence of biofilm did not affect toxicity of the effluent, whereas it decreased significantly the toxicity of Dimethomorph and Chlorpyriphos-ethyl (Fig. 2). About microbial processes, no significant

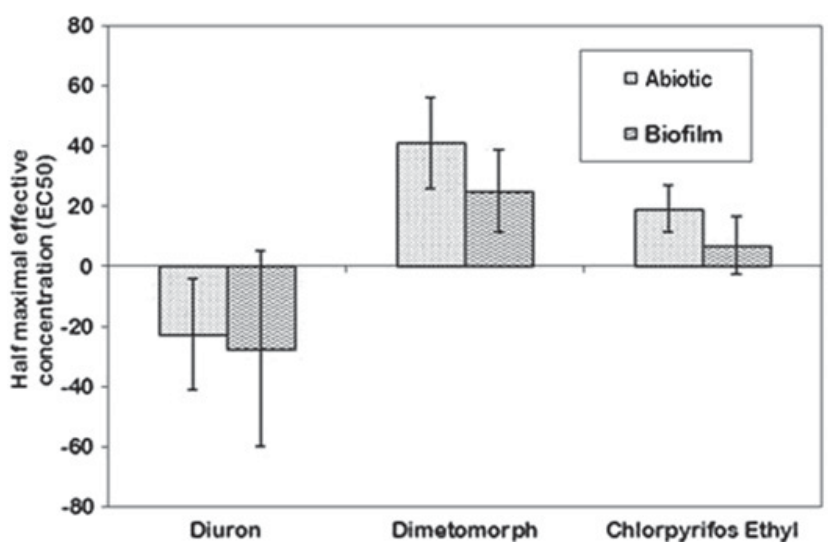

Fig. 2. Rotifer test for Diuron, Chlorpyriphos-ethyl and Dimethomorph additions measured in water 18 days before addition.

differences were observed between biotic and abiotic conditions for potential respiration for Dimethomorph (ANOVA $P<0.001$; Fig. 3a) and for denitrification for Dimethomorph and Chlorpyriphos-ethyl (Fig. 3b). The potential respiration and potential denitrification were less affected in the Diuron/DMSO treatment for both conditions than with the two other pesticides.

\section{Discussion}

\section{The heterotrophic biofilm influence}

The biofilm effect on water quality was measured with direct measurements of toxic concentrations and indirect tests of ecotoxicity. Toxic concentrations gave evidence of initial toxic molecules decreased or metabolite production that is interpreted as enhanced transformation under biofilm influences in this experiment. The Diuron concentration did not significantly change with time and conditions but the first metabolite DCPMU significantly increased with biofilm effects. Under the same biofilm influence Dimethomorph concentration dropped by $60 \%$ in 18 days. These results obtained over a short period experiment suggest increased effects of biofilm over a longer period of time. It also suggests that biofilm could have an important detoxifying effect in natural conditions.

Performed ecotoxicological tests attest to these changes in water quality in the displayed experimental conditions. Although responses vary greatly depending on the test performed, when a change exists in water quality under biofilm activity with positive or negative effects on water toxicity, this change attests to a chemical transformation in the toxic composition of water. The increase or decrease of water toxicity under biofilm effects is codified in Table 1. These results were obtained in the final water of the recycled reservoir that is a mixture of initial molecule and its metabolites. The difference between ecotoxicological test obtained in both conditions (with and without biofilm) is interpreted as a consequence of initial toxicant 
Table 1. Pesticide concentrations used in different additions and comparison of responses of different tests. For each test the toxicity measured with biofilm is compared with toxicity in condition without biofilm. Codes are " - " for increased toxic effect e.g. lower water quality with biofilm; " + " for decreased toxic effect, e.g. better water quality with biofilm; "O" when no biofilm effects are measured.

\begin{tabular}{lccc}
\hline Family & $\begin{array}{c}\text { Herbicide } \\
\text { Dame }\end{array}$ & $\begin{array}{c}\text { Fungicide } \\
\text { Dimethomorph }\end{array}$ & $\begin{array}{c}\text { Insecticide } \\
\text { Chlorpyrifos-ethyl }\end{array}$ \\
\hline Initial concentration $\left(\mu \mathrm{g} . \mathrm{L}^{-1}\right)$ & 30 & 2 & 0,1 \\
Tests & & $\mathrm{O}$ & $\mathrm{O}$ \\
Genotoxicity Xenopus & + & $+^{\mathrm{a}}$ & $+^{\mathrm{a}}$ \\
Rotifer test & $\mathrm{O}$ & $\mathrm{O}$ & - \\
Aerobic respiration & $\mathrm{O}$ & $\mathrm{O}$ & $\mathrm{O}$ \\
Denitrification & $\mathrm{O}$ & & \\
\hline
\end{tabular}

${ }^{a}$ Indicate a significant difference with admitted error $=0.05 \%$ with ANOVA for rotifer and microbial activities and McGill method (McGill et al., 1978) for genotoxicity tests. +, increased toxic effect; - , decreased toxic effect; O, no effect.
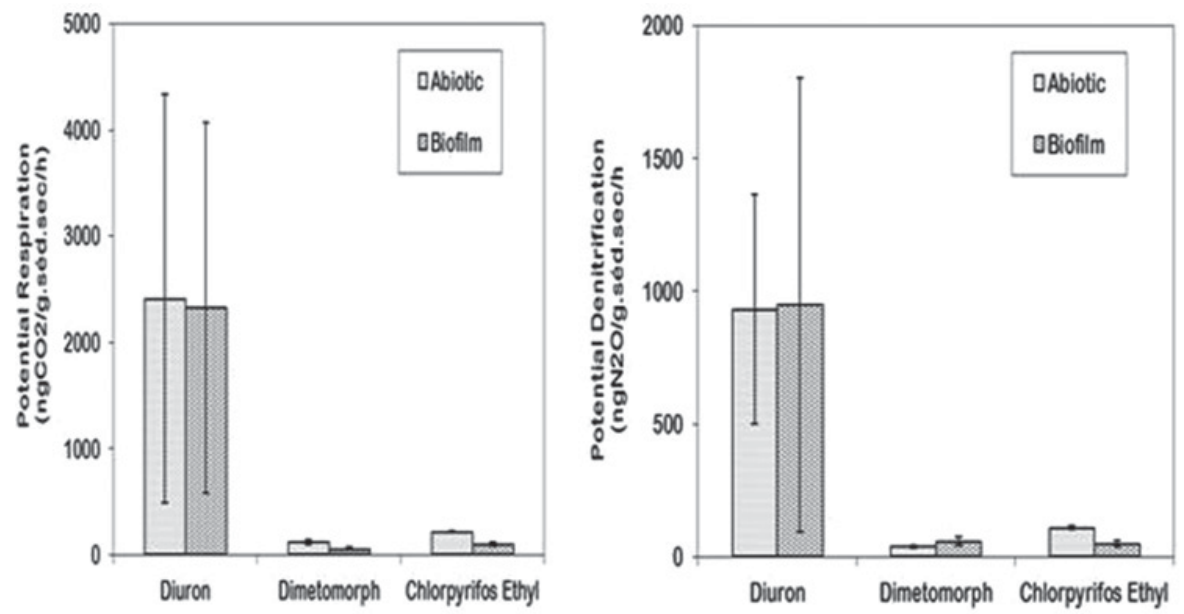

Fig. 3. Respiration (a) and denitrification (b) rates (mean \pm SE, $n=4-6)$ in biofilm condition $(n=4) 18$ days after Diuron, Dimethomorph and Chlorpyrifos-ethyl addition, expressed in microgram per hour and per gram of dry weight sediment $\left(\mu \mathrm{g} \cdot \mathrm{h}^{-1} \cdot \mathrm{g}_{\text {sed DW-1 }}\right)$.

concentration and metabolites creation with different levels of toxicity and concentrations.

The occurrence of different metabolic pathways explains how the same compartment may be efficient at transforming such complex molecules as organic contaminants, and in this way reducing initial pesticides charges. The degradation of Diuron exhibits alternative steps of aerobic, anaerobic and toxic conditions. The efficiency of water purification after filtration through a sediment column with biofilm developed in macroporous media may be explained by the occurrence of different redox conditions along the columns. Aerobic respiration enhanced with $20 \%$ in the biofilm condition demonstrates a more developed aerobic community activity. Water flow and recirculation through these different porous media should permit contact with micro-organisms that perform different degradation steps with various redox potential of a single toxicant. Concerning redox conditions, Baumgarten et al. (2011) outline that bank filtration under aerobic conditions should be suitable to remove SMX to levels below $0.12 \mathrm{mg} . \mathrm{L}^{-1}$. However, previous field studies suggested that organic pollutants were removed more effectively under anoxic (97\%) and anaerobic conditions than under aerobic (64\%) conditions (Schmidt et al., 2004; Jekel and Gruenheid, 2005). The present study suggests that all the required conditions possibly exist in adjacent spots of sediment in a slow filtration column to enable the degradation of organic micropollutants.

\section{Metabolites arrival}

The effects of pesticide transformation due to biofilm activity are not clear, since it includes the production of a mixture of metabolites with various toxicity levels. Ecotoxicological investigations showed different effects depending on the bioassay and the contaminant. Using amphibian larvae, no genotoxic effect was found in abiotic conditions whenever the toxicant and genotoxicity was only highlighted under biofilm influence in Diuron treatment. These results may be related to the measured DCPMU concentration in biotic condition than in abiotic 
one. According to the microtox test in the literature, the metabolite $N$-(3,4-dichlorophenyl- $N$-methylurea and $\mathrm{N}$-3,4-dichlorophenylurea presented three times higher toxicity that that of diuron (Bogaerts et al., 2000; Bonnemoy et al., 2001). The observed genotoxicity in amphibian larvae would then come from DCPMU, rather than Diuron/DMSO. To our knowledge, there are no published genotoxicity studies in the literature concerning amphibian larvae exposed to this metabolite, except the works of Bogaerts et al. (2000) who measured diuron fungal degradation in soil. Schuytema and Nebeker (1998) reported LC50 (The concentration of a substance estimated to be lethal to $50 \%$ of the tested organisms) of 15.2 , 12.7, 22.2 and $11.3 \mathrm{mg} . \mathrm{L}^{-1}$ of Diuron after chronic exposure of 12 or 14 days by amphibian embryos and larvae (Pacific treefrog, bullfrog, red-legged frog and Xenopus).

The affect of DMSO shows contrasted effects: $0.1 \%$ of DMSO is able to change bacterial activity and associated enzymatic process. It is assumed to be possible to affect global microbial metabolism of the interstitial biofilm. Ecological test (not included in the paper) at $48 \mathrm{~h}$ demonstrated no effect of DMSO, alone or mixed with Diuron. Ninety-six hours of expositions (standard period for algae) led to different conclusions with the evidence of a slight DMSO effect of our experimental concentration $(10 \%$ decrease of algae growing rate). However, if the literature (Gordeliy et al., 1998; Griebler and Slezak, 2001) and our tests converge to demonstrate potentiality of DMSO effects, and the change in toxicity of a DMSOdiuron mixture, in the present paper it is the change in the toxicity of DMSO + diuron that is discussed. In the present paper, it is stated that it is the change in the toxicity of the mixture DMSO $0.1 \%$ and diuron that is followed in our experimental condition. If it is demonstrated that there exists a change in the toxicity of water containing the same initial mixture of diuron + DMSO in our experimental condition, and after percolation with and without biofilm effect, the demonstration of biofilm activity in biotransformation of the initial mixture is possible.

In the case of Chlorpyrifos-ethyl, one of its primary metabolites, 3,5,6- trichloro-2-pyridinol (TCP), is less toxic than the parent compound towards aquatic organisms (Giesy et al., 1999). The combination of a minimum of $20 \%$ depletion of initial toxic concentrations and the lower toxicity attested by the rotifer test with this molecule, suggest that biofilm microbial degradation is also active on this type of molecule. The decrease in concentration under the detection limit in all experimental conditions also demonstrates that the sediment matrix should participate in this purification with adsorption processes.

To our knowledge, no information is available concerning metabolites of Dimethomorph and their relative toxicity. However, according to rotifer tests, it is emphasised that microbial activity may also be able to influence this type of toxicant, with metabolite production at lower toxicity than the primary molecule.

\section{Conclusion}

From direct and indirect assessment of the water quality in this short term experiment, it is demonstrated that the presence of a heterotrophic biofilm in a slow filtration column enhances the transformation of the three studied organic micropollutants.

The affects may be enlarged to river conditions with longer residence times due to spiralling functioning and larger spatial conditions with the hyporheic compartment of a natural reach. Since the biomass in sediments with biofilm colonisation influenced the extent of toxic transformation in our laboratory column experiments, further measurements of this transformation are essential to confirm this process in in situ condition. These previous results also suggest that further research on bioremediation of pesticide-contaminated water should for better results include the contribution of heterotrophic biofilm as a biological factor largely involved in degradability. The developed ecological tests applied on residual water suggest that the toxicity of water depends on metabolites production as well as initial molecule concentrations and may vary a lot depending on the initial toxic molecule. This observation should be an encouragement for a more precise assessment of metabolites concentrations in water, through experiments, in order to emphasise in a better manner toxicity variations. Also, this work provides new information to extend self-purification capacity by the benthic boundary layer to a more refractory molecule such as micro-organic toxicants in river waters.

Acknowledgements. We thank the 'InBioProcess' program of the National Research Agency (ANR-2006-BDIV-007). We address special congratulations and acknowledgment to Professor Pierre Marmonier for successful management of the InBioProcess project. Thank you to Arturo Elosegi for comments and corrections.

\section{References}

AFNOR (Association française de normalisation; the French National Organization for quality regulations) 2000. Norme NFT 90- 325. Qualité de l'Eau. Evaluation de la genotoxicité au moyen de larves d'amphibien (Xenopus laevis, Pleurodeles waltl). ICS : $13.020 .40 ; 13.060 .70$. Norme française homologuée, Septembre 2000, Paris: AFNOR. 17.

Baker M.A., Dahm C.N. and Valett H.M., 2000. Anoxia, anaerobic metabolism, and biogeochemistry of the streamwater-groundwater interface. In: Jones J.B. and Mulholland P.J. (eds.), Streams and Ground Waters, Academic Press, Boston, 259-283.

Battin T.J., Kaplan L.A., Newbold J.D. and Hendricks S.P., 2003. A mixing model analysis of stream solute dynamics and the contribution of a hyporheic zone to ecosystem function. Freshwater Biol., 48, 1-20.

Baumgarten B., Jährig J., Reemtsma T. and Jekel M., 2011. Long term laboratory column experiments to simulate bank filtration: factors controlling removal of sulfamethoxazole. Water Res., 45, 211-220. 
Bogaerts P., Bohatier J., Bonnemoy F., Cuer A., Sancelme M., Tixier C., Twagilimana L. and Veschambre H., 2000. Fungal biodegradation of a phenylurea herbicide, diuron: structure and toxicity of metabolites. Pest Manage. Sci., 56, 455-462.

Bonnemoy F., Cuer A., Sancelme M., Tixier C. and Veschambre H., 2001. Degradation products of a phenylurea herbicide, diuron: synthesis, ecotoxicity and biotransformation. Environ. Toxicol. Chem., 30, 1381-1389.

Boulton A.J., Findlay S., Marmonier P., Stanley E.H. and Valett H.M., 1998. The functional significance of the hyporheic zone in streams and rivers. Annu. Rev. Ecol. Syst., 29, 59-81.

Brugger A., Reitner B., Kolar I., Quéric N. and Herndl G.J., 2001. Seasonal and spatial distribution of dissolved and particulate organic carbon and bacteria in the bank of an impounding reservoir on the Enns River, Austria. Freshwater Biol., 46, 997-1016.

Brunke M. and Gonser T., 1997. The ecological significance of exchange processes between rivers and groundwater. Freshwater Biol., 37, 1-33.

Devault D., Gerino M., Laplanche C., Julien F., Winterton P., Merlina G., Delmas F., Lim P., Sanchez Perez J.M. and Pinelli E., 2009. Herbicide accumulation and evolution in reservoir sediments. Sci. Total Environ., 407, 2659-2665.

Everard M. and Powell A., 2002. Rivers as living systems. Aquatic Conserv. Mar. Freshw. Ecosyst., 12, 329-337.

Findlay S., 1995. Importance of surface-subsurface exchange in stream ecosystems: the hyporheic zone. Limnol. Oceanogr., 40, 159-164.

Furutani A., Rudd J.W.N. and Kelly C.A., 1984. A method for measuring the response of sediments microbial communities to environmental perturbations. Can. J. Microbiol., 30, 1408-1414.

Gavrilescu M., 2005. Fate of pesticide in the environment and its bioremediation. Eng. Life Sci., 5, 497-526.

Giesy J.P., Solomon K.R., Coats J.R., Dixon K.R., Giddings J.M. and Kenaga E.E., 1999. Chlorpyrifos: ecological risk assessment in North American aquatic environments. Rev. Environ. Contam. Toxicol., 160, 1-129.

Gifford S., Hugh D. and O'Connor W., 2007. Aquatic zooremediation deploying animals to remediate contaminated aquatic environments. Trends Biotechnol., 25, 60-65.

Gordeliy V.I., Keselev M.A., Lesieur P., Pole A.V. and Teixera J., 1998. Lipid membrane structure and interaction in DMSO/water mixtures. Biophys. J., 75, 2343-2351.

Griebler C. and Slezak D., 2001. Microbial activity in aquatic environments measured by DMSO reduction and intercomparison with commonly used methods. Appl. Environ. Microbiol., 67, 100-109.

Grimm N.B. and Fisher S.G., 1984. Exchange between interstitial and surface water: implications for stream metabolism and nutrient cycling. Hydrobiologia, 111, 219-228.

Gruenheid S., Amy G. and Jekel M., 2005. Removal of bulk dissolved organic carbon (DOC) and trace organic compounds by bank filtration and artificial recharge. Water Res., 39, 3219-3228.

House W.A., Leach D.V. and Armitage P.D., 2001. Study dissolved silicon and nitrate dynamics in a freshwater stream. Water Res., 35, 2749-2757.

Hunter K.S., Wang Y. and Van Cappellen P., 1998. Kinetic modelling of microbially- driven redox chemistry of subsurface environments: coupling transport, microbial metabolism and geochemistry. J. Contam. Hydrol., 209, 53-80.

Ifabiyi I.P., 2008. Self purification of a freshwater stream in Ile-Ife : lessons for water management. J. Hum. Ecol., 24, $131-137$.

ISO, 2006. International Standard. Water quality - Evaluation of genotoxicity by measurement of the induction of micronuclei - Part 1: Evaluation of genotoxicity using amphibian larvae. ISO 21427-1, ICS: 13.060.70, GENOVA - CH, Août 2006, 15.

Janauer G.A., 2000. Ecohydrology : fusing concepts and scales. Ecol. Eng., 16, 9-16.

Jekel M. and Gruenheid S., 2005. Bank filtration and groundwater recharge for treatment of polluted surface waters. Water Sci. Technol.: Water Supply, 5, 57-66.

Landmeyer J.E., Bradley P.M., Trego D.A., Hale K.G. and Haas J.E., 2010. MTBE, TBA, and TAME attenuation in diverse hyporheic zones. Ground Water, 48, 30-41.

Lefebvre S., Marmonier P. and Peiry J.L., 2006. Nitrogen dynamics in rural streams: differences between geomorphologic units. Ann. Limnol. - Int. J. Lim., 42, 43-52.

Lewandowski J., Putschew A., Schweisg D., Neumann C. and Radke M., 2011. Fate of organic micropollutants in the hyporheic zone of a eutrophic lowland stream: results of a preliminary field study. Sci. Total Environ., 409, 1824-1835.

Marmonier P., Archambaud G., Belaidi N., Bougon N., Breil P., Chauvet E., Claret C., Cornut J., Datry T., Dole-Olivier M.-J., Dumont B., Flipo N., Foulquier A., Gérino M., Guilpart A., Julien F., Maazouzi C., Martin D., MermillodBlondin F., Montuelle B., Namour Ph., Navel S., Ombredane D., Pelte T., Piscart C., Pusch M., Stroffek S., Robertson A., Sánchez-Pérez J.M., Sauvage S., Taleb A., Wantzen M. and Vervier Ph., 2012. The role of organisms in hyporheic processes: gaps in current knowledge, needs for future research and applications. Ann. Limnol. - Int. J. Lim., 48, 253-266.

McGill R., Tuckey J. and Larsen W., 1978. Variations of box plots. Am. Statist., 32, 12-16.

Mermillod-Blondin F., Gaudet J.P., Gerino M. and Creuze des Châtelliers M., 2003. Influence of macroinvertebrates on physico-chemical and microbial processes in the hyporheic sediments. Hydrol. Process., 17, 779-794.

Mouchet F. and Gauthier L., 2013. Genotoxicity of contaminants: amphibian micronucleus assay. In: Férard J.F. and Blaise C. (eds.), Comprehensive Handbook (or Practical Guide) of Ecotoxicological Terms, Springer Publishers, Dordrecht, The Netherlands. in press.

Navel S., Sauvage S., Delmotte S., Gerino M., Marmonier P. and Mermillod-Blondin F., 2012. A modelling approach to quantify the influence of fine sediment deposition on biogeochemical processes occurring in the hyporheic zone. Ann. Limnol. - Int. J. Lim., 48, 279-287.

Nieuwkoop D. and Faber J., 1956. Normal Table of Xenopus laevis (Daudin): A Systematical and Chronological Survey of the Development from the Fertilized Egg Till the End of Metamorphosis, North-Holland Publishing Company (Amsterdam), 243.

Orghidan T., 1959. Ein neuer Lebensraum des unterirdischen Wassers: Der hyporheische Biotop. Arch. Hydrobiol., 55, 392-414.

Peyrard D., Sauvage S., Vervier P., Sánchez-Pérez J.M. and Quintard M., 2008. A coupled vertically integrated model to 
describe lateral exchanges between surface and subsurface in large alluvial floodplains with a fully penetrating river. Hydrol. Process., 22, 4257-4427.

Peyrard D., Delmotte S., Sauvage S., Namour Ph., Gerino M., Vervier P. and Sánchez-Pérez J.M., 2011. Longitudinal transformation of nitrogen and carbon transport and in the hyporheic zone of an N-reach stream: a combined modeling and field study. Phys. Chem. Earth, 36, 599-611.

Pusch M. and Schwoerbel J., 1994. Community respiration in hyporheic sediments of a mountain stream (Steina, Black Forest). Arch. Hydrobiol., 130, 35-52.

Pusch M., Fiebig D., Brettar I., Eisenmann H., Ellis B.K., Kaplan L.A., Lock M.A., Naegeli M.W. and Traunspurger W., 1998. The role of micro-organisms in the ecological connectivity of running waters. Freshw. Biol., 40, 453-495.

Sánchez Pérez J.M., Vervier P., Garabetian F., Sauvage S., Loubet M., Rols J.L., Bariac T. and Weng P., 2003. Nitrogen dynamics in the shallow groundwater of a riparian wetland zone of the Garonne, south-western France. Nitrate inputs, bacterial densities, organic matter supply and denitrification measurements. Hydrol. Earth Syst. Sci., 7, 97-107.

Schindler J.E. and Krabbenhoft D.P., 1998. The hyporheic zone as a source of dissolved organic carbon and carbon gazes to a temperate forest stream. Biogeochemistry, 43, 157-174.

Schmidt C.K., Lange F.T. and Brauch H.J., 2004. Assessing the impact of different redox conditions and residence times on the fate of organic micropollutants during riverbank filtration. In: 4th International Conference on Pharmaceuticals and Endocrine Disrupting Chemicals in Water, 13-15 October 2004, Minneapolis, Minnesota.
Schuytema G.S. and Nebeker A.V., 1998. Comparative toxicity of diuron on survival and growth of Pacific treefrog, bullfrog, red-legged frog, and African clawed frog embryos and tadpoles. Arch. Environ. Contam. Toxicol., 34, 370-376.

Stanford J.A. and Ward J.V., 1993. An ecosystem perspective of alluvial rivers: connectivity and the hyporheic. J. N. Am. Benthol. Soc., 12, 48-60.

Storey R.G., Fulthorpe R.R. and Williams D.D., 1999. Perspectives and predictions on the microbial ecology of the hyporheic zone. Freshw. Biol., 41, 119-130.

Sumpono, Perotti P., Belan A., Forestier C., Lavedrine B. and Bohatier J., 2003. Effect of diuron on aquatic bacteria in laboratory-scale wastewater treatment ponds with special reference to Aeromonas species studied by colony hybridization. Chemosphere, 50, 445-455.

Weng P., Sánchez Pérez J.M., Sauvage S., Vervier P. and Giraud F., 2003. Assessment of the quantitative and qualitative buffer function of an alluvial wetland: hydrological modelling of a large floodplain (Garonne River, France). Hydrol. Process., 17, 2375-2392.

White D.S., 1993. Perspectives on defining and delineating hyporheic zones. J. N. Am. Benthol. Soc., 12, 61-69.

Williams J.B., Mills G. and Barnhurst D., 2007. Transport and degradation of a trichloroethylene plume within a stream hyporheic zone. In: Proceedings of the 2007 National Conference on Environmental Science and Technology, 189-194.

Wyss A., Boucher J., Montero A. and Marison I., 2006. Microencapsulated organic phase for enhanced bioremediation of hydrophobic organic pollutants. Enzyme Microbiol. Technol., 40, 25-31. 